\title{
Improving Polyaspartic Anti-Corrosion Coating Protective Properties with the use of Nano-silica
}

\author{
Arezoo Assarian ${ }^{1,{ }^{*}}$ and Sanja Martinez ${ }^{1}$ \\ ${ }^{1}$ University of Zagreb, Faculty of Chemical Engineering and Technology, Department of Electrochemistry, Savska cesta \\ 16/I,10000 Zagreb, Croatia \\ * Corresponding author: E-mail: assarian@fkit.hr \\ Phone: +385991953086; Fax: +38514597260
}

Received: 12-01-2018

\begin{abstract}
The purpose of this study was to investigate and develop a polyaspartic coating, using nano-silica modified with an amino group $\left(\mathrm{NH}_{2}-\right)$ in order to enhance adhesion on metallic surfaces and increase the effectiveness of the coating protective action against corrosion. Seven samples of polyaspartic coating with different amounts of nano-silica were prepared and applied to low carbon steel plates. The results showed that only $2 \%$ of the nano-silica per total weight formulation gave excellent protective as well as physical properties to the coating. The unique result was non-agglomeration and compatibility of nano-particles with the other compounds in the formulation structure. Time dependant behaviour of the coatings was followed by the EIS, SEM and FTIR methods and by exposure in a salt spray chamber. The main advantage was superior mechanical and chemical resistance and durability of a single coat, the properties that reduce emission of VOC and overall cost of the coating application process.
\end{abstract}

Keywords: Polyaspartic coating; Nano-silica; Adhesion; Corrosion; Protective coating

\section{Introduction}

Nowadays, protective coating development is undergoing significant advances due to the new characteristics attained through the application of nano- and micro-fillers. ${ }^{1-3}$ The coating producer's interest in scientific research is driven by the desire to differentiate their products from those of competitors, in the otherwise commodity based industry, by producing coatings of unique characteristics, while at the same time, meeting continually higher and more numerous demands imposed upon the coatings performance. ${ }^{4}$ A range of compulsory requirements is often prescribed for a coating product, in order to make it acceptable form economical and ecological aspects as well as rendering it durable under highly corrosive environments. A serious concern in the field of paint and coatings is that the product life exceeds the coating life, and all manufacturers of coatings are trying to extend the lifetime of coatings. ${ }^{5}$

From preparation to application of coatings on surfaces, there are many factors that are very important and intended to improve the lifetime of coatings. Some of the challenges that play a major role in decreasing the lifetime of coatings are listed below: ${ }^{6}$
- Lack of sufficient adhesion between the surface and coating film

- Low resistance of film coatings to sunlight exposure

- Meager stability of film coatings when exposed to humidity, or corrosive and abrasive environments

- Difficulty in securing stable film coatings due to difficulties in the application of two component coatings, multiple layers of coatings, the accuracy of measurement and application, and the achievement of uniform and homogenous film coatings

- Difficulty to produce an eco-friendly coatings with high performance properties because many of the coating properties are reinforced with organic and inorganic materials, which are hazardous and pollutants ${ }^{7}$

- Excessive energy, manpower, and financial expense Need to maintain and re-apply coatings on coated surfaces due to polymer ageing

- Lack of customer satisfaction due to quality, stability, performance, and overall cost of coating

The main purpose of this research is to formulate a new type of coating for metallic surfaces with the aim of alleviating the aforementioned problems. The general target was 
to increase the productivity of a coating and decrease the volume of volatile organic compound emission. In particular, the study presents an investigation into polyaspartic coating polymer base improvement by using nano-silica filler.

\section{Experimental Details}

The manufacturer of the polyaspartic resin and its hardener used in this research is Covestro (Leverkusen, Germany, formerly Bayer Material Science).

The binder that was used was polyisocyanates with an aminofunctional co-reactant, because it has the ability to form as a high solid, solvent-free, and a topcoat polyurethane coating, whereas the hardener was a solvent-free aliphatic polyisocyanate. The weight ratio of polyisocyanate resin to hardener was $2: 1$. The diameter of $\mathrm{SiO}_{2}$ nanoparticles was $10-20 \mathrm{~nm}$, with a specific surface area of 90-130 $\mathrm{m}^{2} / \mathrm{g}$ obtained from IoLiTec Ionic Liquids Technologies GmbH (Heilbronn, Germany).

For the first step, the start formulation of the coating was considered. Choosing a suitable raw material with regard to the expected coating properties was the most important factor for the start formulation (Table1).

Table 1. Initial composition of the formula

\begin{tabular}{cc}
\hline Binder & $51 \%$ \\
Solvent & $3 \%$ \\
Additives $^{*}$ & $2.5 \%$ \\
Pigments/Extenders & $43.5 \%$ \\
& $100 \%$ \\
\hline
\end{tabular}

* Defoamer, rheology modifier, leveling agent, adhesion promoter, UV stabilizer, dispersing agent, anti-sedimentation agents.

The types of additives used in the coating formulation were carefully selected in order to improve the quality of the coating. One of the most important aims of the coating was to increase adhesion to the metal/coating interface. For this reason, the adhesion promoter Byk-4510 (a solution of a hydroxy-functional copolymer with acidic groups) produced by the company was used and the concentration of Byk- 4510 was $1.1 \%$ based on the total formulation.

In addition, some other different additives were used in order to improve the impact, warp, and scratch resistance and to increase flexibility.

According to recommendations by the nano-silicon oxide manufacturer, the range of use was between $0.1-2.0 \%$ of the weight of the total coating formulation (Table 2).

The samples were produced by increasing the nano -silica percentage. Then their qualities and properties were evaluated respectively in a mechanical laboratory test. ${ }^{9}$

The metal panels were prepared by surface preparation method Sa 2.5 from mild steel $2 \mathrm{~mm}$ thick) with dimensions of $15 \times 10 \mathrm{~cm}$. Using airless spray, the panels were coated with PA7, then after 48 hours they were ready
Table 2. Produced samples using a different amount of the nanosilica

\begin{tabular}{lcc}
\hline No. & Name of the sample & $\begin{array}{c}\text { Amount of nano-silicon } \\
\text { oxide (per weight of total } \\
\text { formulation) }\end{array}$ \\
\hline 1 & PA1 & $0.1 \%$ \\
2 & PA2 & $0.5 \%$ \\
3 & PA3 & $0.9 \%$ \\
4 & PA4 & $1.2 \%$ \\
5 & PA5 & $1.6 \%$ \\
6 & PA6 & $1.9 \%$ \\
7 & PA7 & $2.0 \%$ \\
\hline
\end{tabular}

to set in a salt spray cabinet SF/100 CW (5\% NaCl 99.8\% and $38^{\circ} \mathrm{C}$ ).

Three coated samples with PA7 were considered: 1) PA7-N without any cuts on the surface, 2) PA7-1 with a 7 $\mathrm{cm}$ cut in the center of the panels, 3) PA7-2 with $\mathrm{x}$-cut (7 $\mathrm{cm}$ per cut) in the center of the panel. The degradation of sample PA7 was examined by Fourier transform infrared spectroscopy (FTIR) (PerkinElmer spectrometer Spectrum One, USA) during the exposure in salt chamber. The recorded spectra were in the range of 650 to $4000 \mathrm{~cm}^{-1}$ and under the standard ASTM E1252-98(2007).

The electrochemical impedance spectroscopy (EIS) of the sample PA7 exposed to $3 \% \mathrm{NaCl}$ was measured by PalmSens 3 potenciostat during 446 days. The procedure was done according to ISO 16773-1 to 4 .

Finally, the polyaspartic coating (sample PA7) was applied to the panel with dimensions of $2 \times 2 \mathrm{~cm}$ of low carbon steel and analyzed by SEM and EDX (Tescan Vega III, SBU EasyProbe scanning electron microscope) in order to examine the existing agglomeration of nano-particles in the coating structure. Scanning electron microscopy was conducted with the use of the Tescan Vega III, SBU Easyprobe devices, with a tungsten filament, at a charge of $10 \mathrm{kV}$ (to obtain the picture) and $20 \mathrm{kV}$ (to obtain the X-ray spectrum). Before testing, the sample was steamed with a conductive layer of gold and palladium. ${ }^{10}$

\section{Results and Discussion}

After the coating film on the metal surface dries, it plays a protective role against mechanical and chemical damage. The hardness of the dried coating film is as important as its flexibility. Both of these properties are indirectly related to coating adhesion. If the dried coating film is very hard after the first reverse impact test on the coated metal surface, it creates many micro cracks, which lead to the penetration of humidity, dust, grease, and contaminants under the coating/metal interface layer, and a consequence of this penetration is the loss of adhesion in this area and separation of the dried coating film from the substrate. 
The main structure of the investigated resin is created by the reaction between an aliphatic isocyanate and an aspartic acid ester to create a polyaspartic resin with a urea structure (Fig.1).

This resin has excellent properties such as: fast curing even at ambient temperature, durability, and chemical<smiles>[R]OC(=O)CC(NNC)C(=O)O</smiles><smiles>[R]N=O</smiles><smiles>[R6]NC(=O)N([R1])C(CC(=O)O[R])C(=O)O[R]</smiles>

Aspartic Aliphatic Polyisocyanate

Figure 1. Chemical structure of a polyaspartic coating

resistance. Its two components, high film build and possibility of ultra-high solid content, offer potentially excellent resistance against mechanical damages. ${ }^{11}$

The nano-silica particles were used (silicon oxide, $\mathrm{SiO}_{2}$ ) as an additive in this coating in order to increase and improve adhesion and protective properties. But it was important to create compatibility between extenders, pigments and binder. A combination of anticorrosive pigments was used in the coating, which was improved by nano-silica and sufficient additives. The surface of the nano-silica was modified with an amino group. The reason for selecting this amino group nano-silica was that the alpha amino acid group was used in the coating structure. Besides, it seemed that use of nano-silica was required to increase the adhesion on the coating/metal interface. ${ }^{12}$

The first step was to make a coating sample based on the initial formula. For this purpose, a sufficient amount of polyaspartic acid ester resin was weighed and different additives were respectively added to the resin. It was important to add these additives in this formulation method sequentially. The second essential thing was to select the proper additives based on the chemical structure, because the chemical structures and compatibility of the selected additives were significant issues. ${ }^{13}$ These factors had a major influence on the characteristics of the coating in order to reach the main target, which was to enhance adhesion in the coating/metal interface. ${ }^{14}$ The next major property was surface wettability. Enhancing the degree of wetting is directly related to a suitable and comprehensive distribution of the pigment and extender particles. Therefore, it was necessary, at this stage, to improve the dispersal and wetting of the solid particles in the resin. ${ }^{12-15}$

Samples PA1 and PA2 were rejected because there was flocculation and unstabilized pigment, blushing, and pinholes, which after 24 hours began creating sedimentation and created a sticky layer on the bottom of the coating cans (Figs. 2 and 3). ${ }^{16-18}$

These problems did not appear immediately in samples PA3 and PA4. There was no visual defect in the

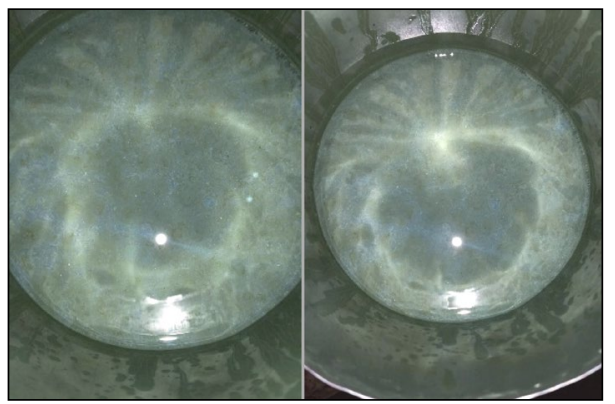

Figure 2. Samples PA1 and PA2 in the can with visible flocculation, unstabilized pigment in vehicle and blushing.

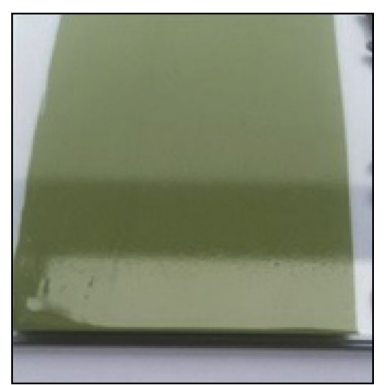

Figure 3. Excessive pinholes on the dried film coating of PA1 and PA2.

liquid coatings but their particle size was not acceptable, so the result of adhesion test was $2 \mathrm{~B} .^{18}$

Sample PA5, with $1.6 \%$ the nano-particles, was rejected because the results of impact and bending (coating flexibility) tests were not acceptable (the results according to ASTM D2794 were $35 \mathrm{~cm}$ direct impact and indirect impact, and coating flexibility according to ASTM D1737 resulted in $18 \mathrm{~mm} / 180^{\circ}$, where an acceptable result is 4 $\left.\mathrm{mm} / 180^{\circ}\right) .{ }^{19}$

In sample PA6, the amount of dispersing and surface agents were increased from $0.3 \%$ of total weight formulation to $0.8 \%$ thereof in order to achieve a better particle size result, but the coating was incompatible with the enhancing quantity of the dispersing agent, as well as nano-silica (Fig. 4). ${ }^{20}$

So after careful consideration, it was concluded that chromium oxide $(\mathrm{Cr} 2 \mathrm{O} 3)$ was the cause of problems in

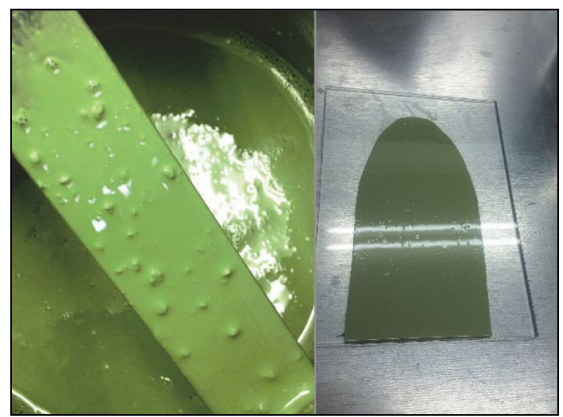

Figure 4. Incompatibility in sample PA6. 
compatibility when the amount of the nano-silica was increased (Fig. 4).

Then sample PA7, with $2.0 \%$ nano-silica was formulated and consequently the quantity of additives was changed proportionally and the main coating formulation in this phase was modified, which eliminated the chromium oxide $\left(\mathrm{Cr}_{2} \mathrm{O}_{3}\right)$. So after that the zinc aluminum orthophosphate hydrate ZPA (manufactured by Heubach $\mathrm{GmbH}$ ) was used instead of chromium oxide $\left(\mathrm{Cr}_{2} \mathrm{O}_{3}\right) .{ }^{21}$

The improved impenetrability property of the coating was achieved with a micronized rutile titanium dioxide pigment treated with alumina and zirconia compounds and a fumed silica that was surface-treated with polydimethylsiloxane (PDMS). These pigments were responsible for providing a well-balanced combination of high durability and very good optical properties and stable rheological performance over time. ${ }^{22}$

The result was excellent, with remarkable improvement in adhesion in the coating/metal interface.

\section{1. Mechanical Results}

The significant test results for PA6 are shown in Table 3. According to the mechanical test, film flexibility intensified due to a lack of sufficient adhesion in the interface PA6 /metal.

Adhesion should be improved as much as expected and appropriate to extend elongation of the coating and remedy related imperfections. ${ }^{1,21}$

Hence, some pigments in the main coating formulation were altered to enhance wetting, consequently reducing the surface tension that was responsible for the sufficient and spontaneous spread of the coating over metal surfaces.

As indicated by the data in Table 4, sample PA7 was a desirable and sought-after coating, as expected.
The final formulation was based on $2 \%$ nano-silica (99.8\%, with amino group), but the main concern was the structure of nano-particles in the coating, because they have a tendency to be an elastomer. In this case, the coating wettability was expected to decrease, and to solve this problem two different vital additives were used to enhance the wetting and dispersing agent. ${ }^{23-25}$

The molecule size of additives was quite important, so there is a possibility that large molecules in instant dispersant additives retain the nanoparticles inside their massive volume and trap them. This was considered in the selection of a nano-dispersing agent to disperse the nano-silica. ${ }^{25}$

The wetting and dispersing additive structures are amphiphilic, which means both of them possess hydrophilic and lipophilic properties and the difference between them is that the wetting agent has a very low molecular weight and dispersing additives have a high molecular weight. ${ }^{26}$

Generally, nano-silica may provide a high level of scratch and wear resistance that indirectly affect adhesion. It is clear that the adhesion strength of coating depends on many factors such as suitable wetting and spread of the liquid phase (coating), time, pressure, and temperature, the chemical compatibility of the material, surface roughness, etc. ${ }^{26-28}$

Sample PA7 in the first step indicated a lack of adhesion after $1000 \mathrm{~h}$ in the salt spray test, which was demonstrated by considerable blistering around the entire panel, as shown in Fig. 5.

This result showed that the amount of adhesion promoter and surface agent additive should be increased to enhance adhesion of sample PA7 under arduous situations and in case of mechanical damage..$^{29,30}$

The adhesion promoter (Byk-4510) that was used is a hydroxy-functional copolymer with acidic groups. Obviously the silicon-free adhesion promoter with acidic groups caused an intense chemical affinity, especially to metallic surfaces. BYK-4510 reacts with polyisocyanates and is consequently

Table 3. Mechanical result of sample PA6

\begin{tabular}{lcccc}
\hline No. & Name of test & Result & Acceptable result & Standard method \\
\hline 1 & Fineness & 15 micron & OK & ASTM D1210 \\
\hline 2 & Adhesion & $4 \mathrm{~B}$ & ASTM D3359 \\
\hline 3 & Film Flexibility & $10 \mathrm{~mm} / 180^{\circ}$ & $4 \mathrm{~mm} / 180^{\circ}$ & ASTM D522 \\
\hline 4 & Impact & $\begin{array}{c}\text { Direct } 55 \mathrm{~cm} \\
\text { Reverse } 70 \mathrm{~cm}\end{array}$ & ASTM D2794 \\
\hline 5 & Surface drying time $20^{\circ} \mathrm{C}$ & $48 \mathrm{~min}$ & Reverse $90 \mathrm{~cm}$ & ASTM D1640 \\
\hline 6 & Drying time $20^{\circ} \mathrm{C}$ & $30 \mathrm{~min}$ & $1 \mathrm{~h}$ & ASTM D1640 \\
\hline 7 & Dry to handle $20^{\circ} \mathrm{C}$ & $1 \mathrm{~h}$ and $53 \mathrm{~min}$ & $5 \mathrm{~h}$ & ASTM D1640 \\
\hline 8 & Hardness by Konig after 7 days & $11 \mathrm{~h}$ & $250 \mathrm{~s}$ & ASTM D4366 \\
\hline 9 & Pot life & $181 \mathrm{~s}$ & $2 \mathrm{~h}$ & ASTM D2196 - 15 \\
\hline
\end{tabular}




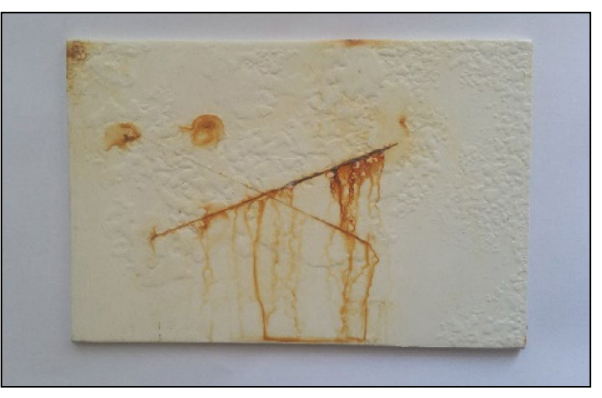

Figure 5. PA7 after 1000h under the salt spray test before adding more adhesion promoter and surface agent.

merges in the polymer matrix. The adhesion promoter, without reduction of hardness, may improve the flexibility of the coating but it is dependent on the coating system.
The adhesion test results are presented in Table 4, which shows that the complete wetting and low surface tension of sample are the two main factors in improving adhesion, and the result according to the cross-cut test was excellent (5B). Also, Fig. 6 shows that the horizontal and X-cut damage to the surface of the coated by PA7 are protective and as strong as the sample PA7-N (without any damage).

\section{2. Scanning Electron Microscopy (SEM):}

The polyaspartic coating (sample PA7) was applied to the panel of low carbon steel with dimensions of $2 \times 2$ $\mathrm{cm}$ and analyzed by SEM and EDX (Tescan Vega III, SBU EasyProbe scanning electron microscope) in order to examine the existence of agglomeration of nano-particles in the coating structure. The evaluation was done under acce-

Table 4. Mechanical results of sample PA7 as a final formulation

\begin{tabular}{|c|c|c|c|c|c|}
\hline No. & Name of test & Result & Acceptable result & Standard method & Remark \\
\hline 1 & Fineness & 15 micron & OK & ASTM D 1210 & \\
\hline 2 & Adhesion & $5 B$ & $5 B$ & ASTM D3359 & \\
\hline 3 & Film Flexibility & $2 \mathrm{~mm} / 180^{\circ}$ & $4 \mathrm{~mm} / 180^{\circ}$ & ASTM D522 & \\
\hline 4 & Impact & $\begin{array}{l}\text { Direct } 100 \mathrm{~cm} \\
\text { Reverse } 100 \mathrm{~cm}\end{array}$ & $\begin{array}{l}\text { Direct } 80 \mathrm{~cm} \\
\text { Reverse } 90 \mathrm{~cm}\end{array}$ & ASTM D2794 & \\
\hline 5 & Surface drying time & $20 \mathrm{~min}$ & $30 \mathrm{~min}$ & ASTM D1640 & $20^{\circ} \mathrm{C}$ \\
\hline 6 & Drying time & $45 \mathrm{~min}$ & $1 \mathrm{~h}$ & ASTM D1640 & $20^{\circ} \mathrm{C}$ \\
\hline 7 & Dry to handle & $5 \mathrm{~h}$ & $5 \mathrm{~h}$ & ASTM D1640 & $20^{\circ} \mathrm{C}$ \\
\hline 8 & Hardness & $261 \mathrm{~s}$ & $250 \mathrm{~s}$ & ASTM D4366 & $\begin{array}{c}\text { By Konig after } 7 \text { days, } \\
\text { Test method A }\end{array}$ \\
\hline 9 & Pot life at $25^{\circ} \mathrm{C}$ & $3 \mathrm{~h}$ & $2 \mathrm{~h}$ & ASTM D2196 - 15 & \\
\hline 10 & Volume solid & $86 \%$ & $87 \%$ & ASTM D5201 - 05a & may vary by color \\
\hline 11 & Density & $1.47 \mathrm{~g} / \mathrm{l}$ & $1.5 \mathrm{~g} / 1$ & ASTM D 1475 & \\
\hline 12 & VOC & $114 \mathrm{~g} / \mathrm{l}$ & $120 \mathrm{~g} / \mathrm{l}$ & ASTM D2369 - 10 & \\
\hline 13 & Theoretical coverage & $16 \mathrm{Sq} \mathrm{m} / \mathrm{L}$ & $12 \mathrm{Sq} \mathrm{m} / \mathrm{L}$ & & \\
\hline 14 & Settling & 10 & 10 & ASTM D869 & $\begin{array}{c}10 \rightarrow \text { perfect suspension } \\
\text { and } 0 \rightarrow \text { fail }\end{array}$ \\
\hline 15 & Dry film thickness & 85 micron & N/A & ISO 2808 & \\
\hline 16 & Sag resistance & No sagging & N/A & ASTM D4400 & $(75-300 \mu \mathrm{m})$ \\
\hline 17 & Wet film thickness & 100 micron & N/A & ASTM D1212 & \\
\hline 18 & $\begin{array}{c}\text { Weathering resistance, } \\
\text { UVA } 340 \mathrm{~nm}\end{array}$ & $\begin{array}{c}<2100 \mathrm{~h} \\
\text { No chalking }\end{array}$ & N/A & ASTM D4587 & $\begin{array}{c}\text { Cycle: } 8 \mathrm{~h} \mathrm{UV} / 4 \mathrm{~h} \\
\text { condensation, } 60 \pm 5^{\circ} \mathrm{C}\end{array}$ \\
\hline 19 & $\begin{array}{l}\text { Corrosion resistance } \\
\text { (salt spray) }\end{array}$ & $\begin{array}{l}2500 \mathrm{~h}, \text { no rust and } \\
\text { blisters on the panel with }\end{array}$ & N/A & ASTM B117 & $\begin{array}{l}\text { Dry film thickness of the } \\
\text { horizontal cut } \\
\text { tested panel was } 200 \mu \text {. }\end{array}$ \\
\hline 20 & Gloss & $\begin{array}{c}60^{\circ}-98 \text { (before UV test) } \\
60^{\circ}-86 \text { (after } 2000 \mathrm{~h} \\
\text { of UV test) }\end{array}$ & N/A & ASTM D523 & $\begin{array}{c}\text { After } 2000 \text { h in UVA cabinet } \\
\text { the reduction was } \\
\text { approximately } 12 \%\end{array}$ \\
\hline
\end{tabular}


a)

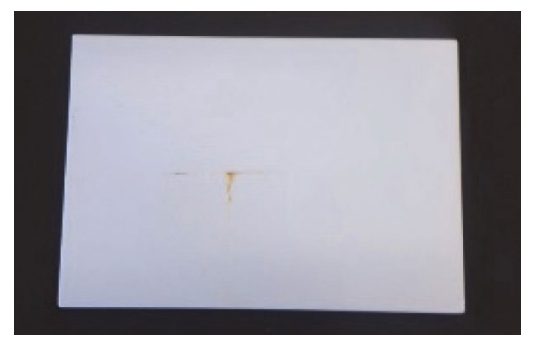

b)

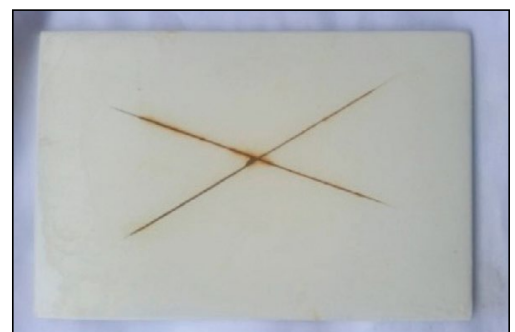

Figure 6. (a) Coated panel with PA7-N coating with horizontal cutting after 2500 hours in a salt spray cabin and (b) panel with PA7-N coating and $\mathrm{X}$-cut after 2500 hours in a salt spray cabin.

lerating voltage of electron beam $(10 \mathrm{kV})$ and at different magnifications. ${ }^{10}$

An analysis of the protective coating on the metal substrate via scanning electron microscopy (SEM) with energy dispersive X-ray spectrometry (EDX) was performed. The analysis should determine the possibility of presence of any agglomerates of the $\mathrm{SiO}_{2}$ nano-particles in the dried coating film structure. SEM micrograph of the PA7 coating is shown in Fig. 7.

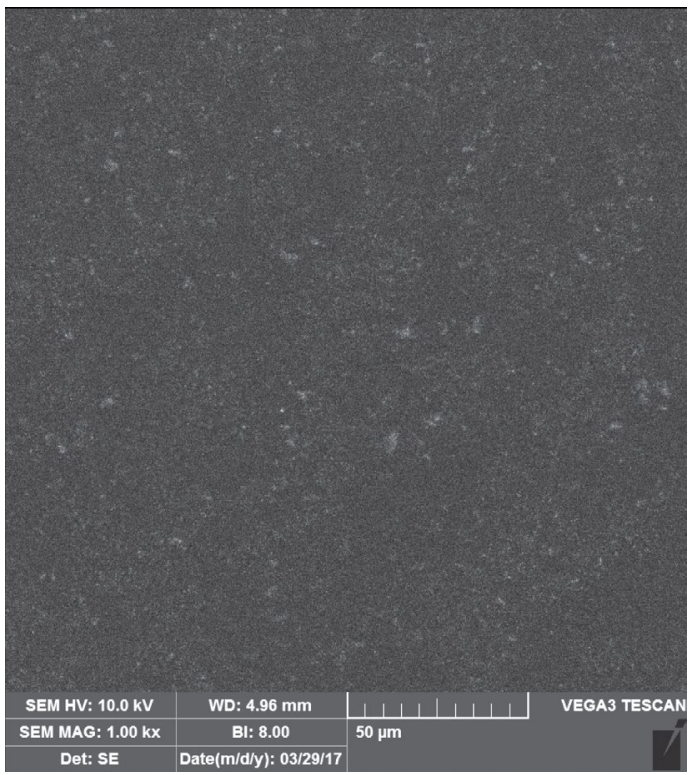

Figure 7. SEM micrograph of the PA7 coating.

Larger particles were observed in the dried film of sample PA7, but the EDX analysis (not shown) confirmed that in all cases those were pigment or filler particles. No signs of agglomerates of $\mathrm{SiO}_{2}$ nano-fillers were detected. ${ }^{31}$

\section{3. Electrochemical Impedance Spectroscopy (EIS)}

In impedance spectroscopy, a small sinusoidal voltage was applied to the sample over a wide frequency range, from $10^{4}$ to $10^{-2} \mathrm{~Hz}$. The controlling computer system recorded the extent of current induced by the potential and also the phase angle between the potential and current maxima. ${ }^{32}$ High-performance sample PA7 was exposed to $5 \% \mathrm{NaCl}$ at $38^{\circ} \mathrm{C}$ for 446 days and the impedance was measured continually. Fig. 8 shows Nyquist plots for different exposure times. Sample PA7 initially had very high impedance but its impedance slowly declined over time and then rose again.

The impedance of protective coatings at $0.1 \mathrm{~Hz}$ may be taken as an indicator of the protective capacity of the coating. High quality coatings are excellent electrical insulators and typically have electrical resistivity greater than $10^{9} \mathrm{ohm} \mathrm{cm}^{2}$. Coatings of good quality have resistivity between $10^{8}$ and $10^{9} \mathrm{ohm} \mathrm{\textrm {cm } ^ { 2 }}$, fair-quality coatings have resistivity between $10^{6.5}$ and $10^{8} \mathrm{ohm} \mathrm{cm}^{2}$, and poor coatings have resistivity lower than $10^{6.5} \mathrm{ohm} \mathrm{cm}{ }^{2} .{ }^{30} \mathrm{Fig}$. 8 shows variation at $0.1 \mathrm{~Hz}$ over time. As may be seen, after 446 days the result demonstrated impedance that was higher than 10 , meaning excellent protection from corrosion. The average impedance logarithm equals 9.50 \pm 0.44 .

From the impedance recorded at $100 \mathrm{~Hz}$, the capacitance, dielectric constant and water uptake of the coating (shown in Fig. 9) may be calculated by the following formulas: ${ }^{33}$

$$
\begin{aligned}
& C=\frac{1}{2 \pi f|Z|_{@ 100 H z}} \\
& \varepsilon_{r}=\frac{C d}{\varepsilon_{0} A} \\
& \varphi=\frac{\log _{10}\left(C_{t} / C_{0}\right)}{d \log _{10} \varepsilon_{W}}
\end{aligned}
$$

Where,

$C=$ coating capacitance

$C_{0}=$ initial coating capacitance

$C_{\mathrm{t}}=$ coating capacitance over time $\mathrm{t}$

$\varepsilon_{0}=$ vacuum electrical permittivity

$\varepsilon_{\mathrm{r}}=$ relative electrical permittivity (dielectric)

$\varepsilon_{\mathrm{W}}=$ water electrical permittivity 
$\varphi=$ water uptake

$A=$ surface area of a panel and, $d=$ coating thickness

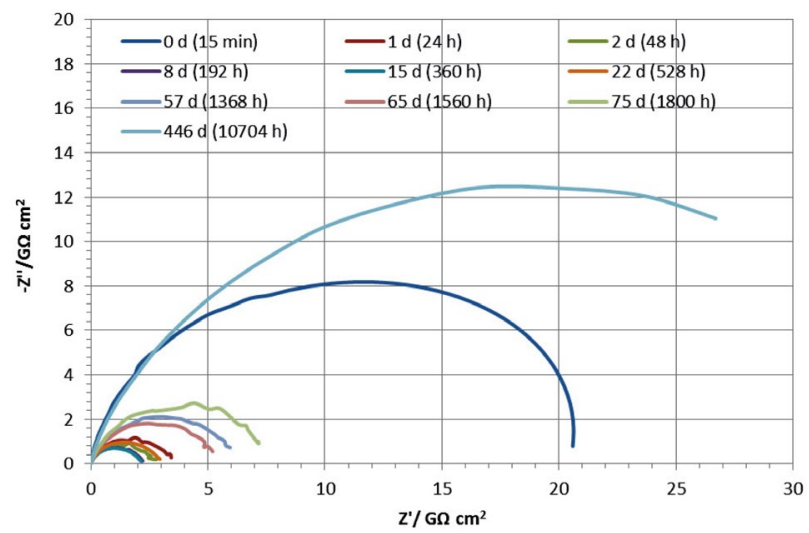

Figure 8. EIS spectra of the test panel as a function of immersion time (Nyquist plot $-\log \mathrm{IZ}_{\mathrm{Re}} \mathrm{I}$ vs. $\log \mathrm{IZ}_{\mathrm{Im}} \mathrm{I}$ ) during $466 \mathrm{~d}$.

The average value of capacitance equals $1.30 \pm 0.13$ $\mathrm{nF} \mathrm{cm} \mathrm{cm}^{-2}$, of the dielectric constant $4.43 \pm 0.45$ and of the water uptake $7.12 \pm 1.41 \%$. These values indicate that the coating has retained its protective properties throughout the exposure period..$^{34,35}$

\section{4. Fourier Transform- Infrared Spectroscopy (FTIR)}

The degradation of sample PA7 was studied by Fourier transform infrared (FTIR) spectroscopy, as this is the standard method for predicting the long-term degradation and performance of the film coating. So the characterizations of sample PA7-N were evaluated by FTIR before starting the corrosion resistance test. The recorded spectra were within a range of 650 to $4000 \mathrm{~cm}^{-1}$ and under the standard ASTM E1252-98(2007). ${ }^{34}$ FTIR is a practical

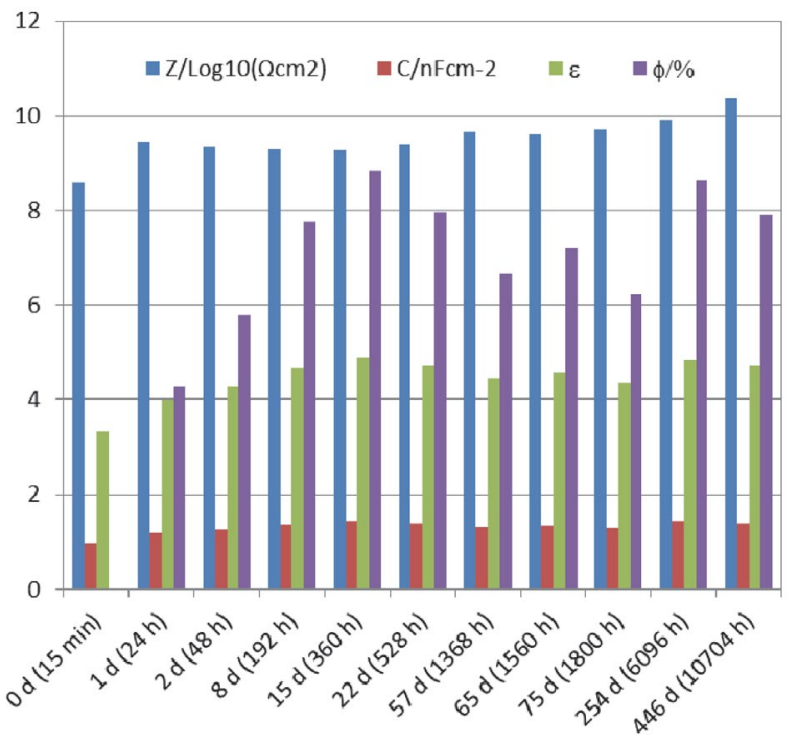

Figure 9. PA7 coating parameters calculated from EIS measurements for different times of exposure to $3.5 \% \mathrm{NaCl}$.

technique for evaluating and diagnosing the reason for decreasing adhesion in organic coatings.

The main absorption bands were demonstrated at $\approx 3356 \mathrm{~cm}^{-1} ; \approx 2927 \mathrm{~cm}^{-1} ; \approx 2856 \mathrm{~cm}^{-1} ; \approx 1713 \mathrm{~cm}^{-1} ; \approx 1519$ $\mathrm{cm}^{-1} ; \approx 1453 \mathrm{~cm}^{-1} ; \approx 1361 \mathrm{~cm}^{-1}, \approx 1218 \mathrm{~cm}^{-1}$, and $\approx 1016$ $\mathrm{cm}^{-1}$, which may be appropriate for the vibration of groups $\mathrm{N}-\mathrm{H}, \mathrm{C}-\mathrm{H}, \mathrm{C}=\mathrm{O}$ (ester), $\mathrm{C}=\mathrm{O}$ (amide), $\mathrm{CH} 2$, and $\mathrm{CH} 3$. Therefore, these graphs indicate the presence of the ester and amine groups. The band at $3356 \mathrm{~cm}^{-1}$ is attributed to the $\mathrm{N}-\mathrm{H}$ cause of polyurethane. However, the absorption bands there are at $\approx 1218 \mathrm{~cm}^{-1} ; \approx 1016 \mathrm{~cm}^{-1}$ with emphasis on the vibration of the $\mathrm{Si}-\mathrm{O}$ groups. The absorbance intensity value of the bands remained unchanged during research. ${ }^{35}$ Consequently, during the first day up to $2500 \mathrm{~h}$ exposure in the salt spray cabinet there was no degradation (as shown in

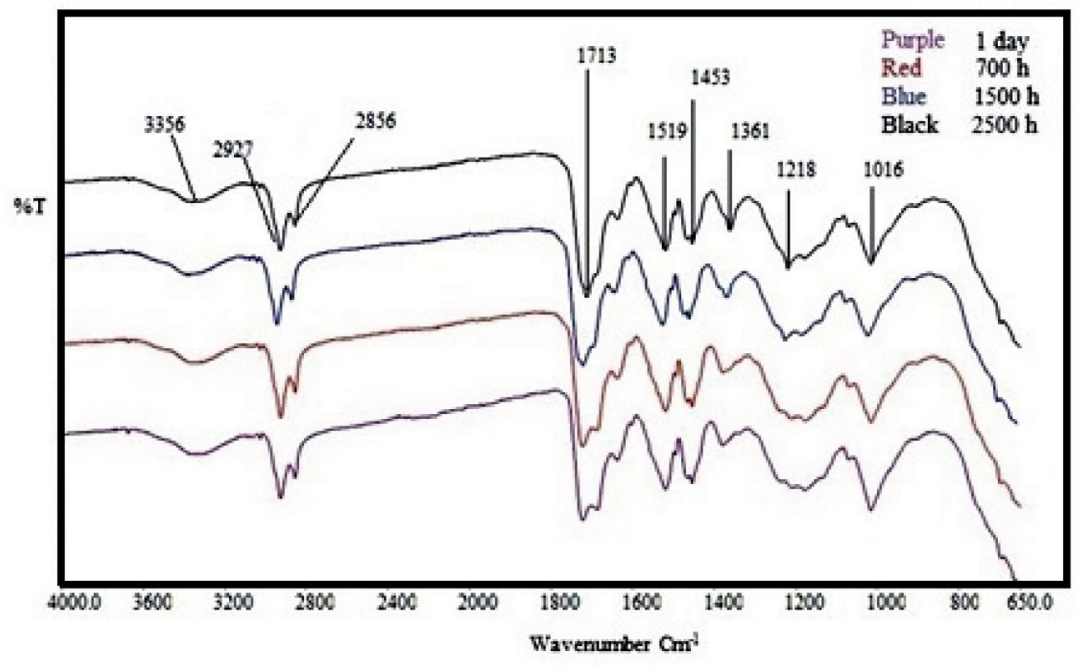

Figure 10. FTIR spectrum of the polyaspartic coating of sample PA7. 
Table 5. Comparison of some properties of the improved polyaspartic coating and conventional anti-corrosive coating systems.

\begin{tabular}{|c|c|c|c|c|c|}
\hline No. & $\begin{array}{l}\text { Property in corrosivity category } \\
\text { C5-M Very high (Marine) }\end{array}$ & Sample A & Sample B & Sample C & Sample D \\
\hline 1 & VOC & $114 \mathrm{~g} / \mathrm{L}$ & $250 \mathrm{~g} / \mathrm{L}$ & $442 \mathrm{~g} / \mathrm{L}$ & $276 \mathrm{~g} / \mathrm{L}$ \\
\hline 2 & Coverage & $16 \mathrm{Sq} \mathrm{m} / \mathrm{L}$ & $8 \mathrm{Sq} \mathrm{m} / \mathrm{L}$ & 7-9 Sq m/L & $10 \mathrm{Sq} \mathrm{m} / \mathrm{L}$ \\
\hline 3 & Dry to handle time at $25^{\circ} \mathrm{C}$ & $8 \mathrm{~h}$ & $12 \mathrm{~h}$ & $24 \mathrm{~h}$ & $24 \mathrm{~h}$ \\
\hline
\end{tabular}

Fig. 10), which means it has high adhesion in the boundary layer and it is expected to have a long-term service life. The results also indicated that the degradation on the film coating of the sample could be considered negligible.

\section{4. Comparison of Results}

Table 5 demonstrates the comparative results of the improved polyaspartic coating and the conventional commercially available protective coating system for a highly corrosive environment such as splash zones.

As seen in Table 5, there is an immense difference in results. The VOC has been significantly decreased. In addition, the coverage of the coating has been increased practically in comparison to other coating samples. Drying time has been decreased.

\section{Conclusion}

The polyaspartic coating polymer base was improved by adding nano-silica. The coating applied directly to the carbon steel surface in a thin layer of 85 micron DFT showed excellent protection against chemical and mechanical damage. According to the test results, this coating reduces the number of layers to be applied compared to the conventional coating systems, has high resistance, ultra-low volatile organic compound (VOC) content (114 $\mathrm{g} / \mathrm{L}$ ), and consequently reduces maintenance costs and environmental impact.

Various coating characteristics indicate that it has retained its protective properties throughout the period of exposure of $2500 \mathrm{~h}$ in the salt spray cabinet, showing no signs of degradation, as confirmed by FTIR measurements. Additionally, SEM and EDX analysis results show no signs of agglomeration of nano-silica filler. High coating impedance $\left(>10^{9} \mathrm{Wcm}^{2}\right)$ was retained throughout the period of $10704 \mathrm{~h}$ of exposure to $3 \% \mathrm{NaCl}$ solution, while the coating capacitance remained practically constant, and water uptake remained $<9 \%$, so the results indicate that using nano-silica with other suitable pigments and additives in the coating formulation provides resilient coating with good prospects of attaining long service lifetime. According to these results, the investigated nano-silica polyaspartic coating shows outstanding properties and presents a significant progress in formulating nanocomposite protective coating systems.

\section{Acknowledgments}

I would like to thank Prof. Marko Rogošič, Ph.D., for his assistance and support.

\section{References}

1. T. B. T. Nguyen, N. T. Nguyen, T. H. Ha, B.T.T Nguyen, Viet. J. Sci. Tech. 2017, 55, 153-163.

2. Z. S. Poura, M. Ghaemya, S. Bordbarb, H. Karimi-Malehc, Prog. Org. Coat. 2018, 119, 99-108.

DOI:10.1016/j.porgcoat.2018.02.019

3. S. B. Ulaetoa, R. Rajana, J. K. Pancreciousa, T.P.D. Rajana, B.C. Paia, Prog. Org. Coat. 2017, 111, 294-314.

DOI:10.1016/j.porgcoat.2017.06.013

4. J. Viertel, L. Neuer, B. Mauch, T. Czyborra, Mater. Corros. 2017, 68, 1321-1325. DOI:10.1002/maco.201709464

5. J. W. Martin, Methodologies for Predicting the Service Lives of Coating Systems, DIANE Publishing, USA, 1994, pp. 1-34. DOI:10.6028/NIST.BSS.172

6. W. M. Bos, T. Bos, Prediction of Coating Durability - Early Detection Using Electrochemical Methods, Gildeprint Drukkerijen B.V., Enschede, The Netherlands, 2008, pp. 1-139.

7. J. R. Davis, Corrosion: Understanding the Basics, ASM International, USA, 2000, pp. 1-49.

8. T. Bäker, M. Casimir, M. Homann, Paint Coat. Ind. 2007, 23, 40-42.

9. G. Gündüz, Chemistry, Materials, and Properties of Surface Coatings: Traditional and Evolving Technologies, DEStech Publications, Inc, USA, 2015, pp. 641-701.

10. X. J. Raj, T. Nishimura, International Journal of Petrochemical Science \& Engineering 2017, 2, 00028.

DOI:10.15406/ipcse.2017.02.00028

11. K. H. Wuehrer, Bringing Polyaspartic Technology to the Next Level: Low Viscous Solvent-free Floor Coatings, ENVVT 2014 / 2014-11-25.

12. A. Goldschmidt, H. J. Streitberger, BASF Handbook on Basics of Coating Technology, Vincentz, Germany, 2003, pp. 27-253.

13. John J. Florio, Daniel J. Miller, Handbook of Coating Additives, CRC Press, USA, 2004, pp. 145-159. 
14. A. Forsgren, Corrosion Control Through Organic Coatings, CRC Press Taylor \& Francis Group, USA, 2006, pp. 11-51. DOI:10.1201/9781420007022.ch2

15. A. A. Tracton, Coating Technology Fundamentals, Testing and Processing Technology, CRC Press Taylor \& Francis Group, New York, 2007, pp. 1-18.

16. R. Lambourne, T. A. Strivens, Paint and Surface Coatings; Theory and Practice, Vol. 2, William Andrew Publishing, USA, 1999, pp. 185-283.

17. J. Bieleman, Additives for Coatings, Wiley-Vch Press, Germany, 2000, pp. 65-224. DOI:10.1002/9783527613304.ch4

18. P. A. Sørensen, S. Kiil, K. Dam-Johansen, C. E. Weinell, J. Coat. Technol. Res. 2009, 6, 135-176. DOI:10.1007/s11998-008-9144-2

19. A. S. Khanna, High-Performance Organic Coatings, CRC Press, USA, 2008, pp. 56-120.

20. G. T. Bayer, M. Zamanzadeh, Failure Analysis of Paints and Coatings, Matco Associates, PA, 2004.

21. Z. W. Wicks Jr, F. N. Jones, S. P. Pappas, Organic Coatings: Science and Technology, 2nd ed., Wiley-Interscience, New York, 1999, pp. 675-680.

22. G. Gündüz, Chemistry, Materials, and Properties of Surface Coatings: Traditional and Evolving Technologies, DEStech Publications, Inc, USA, 2015, pp. 343-515.

23. M. M. Mirza, E. Rasu, A. Desilva, Int. J. Chem. Eng. Appl. 2016, 7, 221-225.

24. P. A. Schweitzer, Paint and Coatings; Applications and Corrosion Resistance, CRC Press Taylor \& Francis Group, USA, 2006, pp. 19-245.
25. S. Pilotek, F. Tabellion, Eur. Coat. J. 2005, 170, 04.

26. E. M. Petrie, Handbook of Adhesives and Sealants, MacGrawHill, USA, 2000, pp. 49-89, 253-273.

27. M. A. Butt, A. Chughtai, J. Ahmad, R. Ahmad, U. Majeed, I. H. Khan, Journal Faculty of Engineering \& Technology 2008, $15,21-45$.

28. A. Jarray, V. Gerbaud, M. Hémati, Powder Technol. 2015, 271, 61-75. DOI:10.1016/j.powtec.2014.11.004

29. American National Standards Institute, Test Procedure and Acceptance Criteria for Factory Applied Finish Coatings for Steel Doors and Frames, Steel Door Institute, USA, 2012.

30. H. L. Lee, Fundamental of Adhesion, Springer Science \& Business Media, New York, 2013, p. 14.

31. X. Shi, T. A. Nguyen, Z. Suo, Y. Liu, R. Avci, Surf. Coat. Technol. 2009, 204, 237-245.

DOI:10.1016/j.surfcoat.2009.06.048

32. E. Barsoukov, J. R. Macdonald, Impedance Spectroscopy: Theory, Experiment, and Applications Wiley-Interscience, USA, 2005, pp. 129-205. DOI:10.1002/0471716243

33. C. Moreno, S. Hernandez, J. J. Santana, J. Gonzalez-Guzman, R. M. Souto, S. Gonzalez, Int. J. Electrochem. Sci. 2012, 7, 8444- ww8457.

34. B. Stuart, Infrared Spectroscopy: Fundamentals and Applications, Wiley, England, 2004, pp. 15-135.

DOI:10.1002/0470011149

35. X. F. Yang, C. Vang, D. E. Tallman, G. P. Bierwagen, S. G. Croll, S. Rohlik, Polym. Degrad. Stab. 2001, 74, 341-351. DOI:10.1016/S0141-3910(01)00166-5

\section{Povzetek}

$\mathrm{V}$ pričujočem prispevku smo želeli raziskati in razviti poliaspartatne prevleke $\mathrm{z}$ uporabo nano $\mathrm{SiO}_{2}$ modificiranega $\mathrm{z}$ amino skupino $\left(\mathrm{NH}_{2}-\right)$ z namenom povečanja adhezije na kovinskih površinah in učinkovitejše zaščite proti koroziji. Pripravili smo sedem vzorcev poliaspartatne prevleke $\mathrm{z}$ različnimi količinami nano $\mathrm{SiO}_{2}$ in jih nanesli na pločevine $\mathrm{z}$ nizko vsebnostjo ogljika. Rezultati so pokazali, da je le $2 \%$ nano-silicijevega dioksida na celotno masno sestavo zagotovilo odlične zaščitne in fizikalne lastnosti prevleke. Pomemben rezultat je tudi združljivost nanodelcev z drugimi spojinami v sestavi premaza. Časovno odvisno obnašanje prevlek smo sledili z metodami EIS, SEM in FTIR ter izpostavitvi v komori za razprševanje soli. Glavna prednost tako pripravljenih prevlek je bila odlična mehanska in kemična odpornost ter obstojnost enoslojnega premaza in hkrati zmanjšana emisija hlapnih organski spojin ter nižji skupni stroški postopka nanosa premaza. 